\title{
FIELDING AND ITALIAN OPERA
}

\author{
CHARLES TRAINOR* \\ Siena College, New York
}

\begin{abstract}
As his era's most prolific writer of ballad operas, Henry Fielding knew music well and was particularly outspoken about Italian opera, the reigning London fashion of the day. While he recognized how moving its "soft alluring Strain" could be, as a nationalist he resented the imported form, which he feared would corrupt and emasculate the English. Moreover, if he objected to it on moral grounds, he did so on aesthetic ones as well. As a believer in the supremacy of the word, he regarded the genre's elevation of music over text as a reversal of the proper hierarchy; and with the operas performed in a language that the audience did not understand, he saw them as failing in art's basic mission to inform and instruct. Indeed, in the eyes of Fielding and many of his literary peers, Italian opera came to symbolize the ultimate triumph of sound over sense.
\end{abstract}

Keywords: Fielding, Italian opera, castrati, eighteenth century, ballad opera.

\section{FIELDING Y LA ÓPERA ITALIANA}

RESUMEN. Fielding, el escritor más prolífico de su época en lo que a ópera de baladas se refiere, conocía muy bien la música y era particularmente categórico con respecto a la ópera italiana. Aunque reconocía lo emotivo que podía ser su "encantador tono suave", repudiaba las formas importadas, que temía, pudieran corromper las formas inglesas. Además, si se oponía a ella en terrenos morales, también lo hacía en lo estético. Consideraba la elevación de la música del género

\footnotetext{
* Correspondence should be sent to: Dr. Charles Trainor. Siena College. English Department. 515 Loudon Road. Loudonville, NY 12211 USA. E-mail: trainor@siena.edu
} 


\begin{abstract}
por encima del texto como una inversión de la correcta jerarquía, y con las óperas ejecutadas en un idioma que la audiencia no entendía, vio su falla en la misión básica del arte de instruir. De hecho, a los ojos de Fielding y a los ojos de muchos de sus pares literarios, la ópera italiana llegó a simbolizar el triunfo final del sonido sobre el sentido.
\end{abstract}

Palabras clave: Fielding, ópera italiana, castrati, siglo XVIII, ópera de baladas.

While the same cannot be said of all his literary contemporaries, ${ }^{1}$ Henry Fielding's musical expertise has never been in doubt. If he wrote his great comic novels in the 1740's, during the 1730's he had an equally successful career as his era's most productive composer of ballad operas. Established and popularized in 1728 by Gay's The Beggar's Opera, this genre borrowed established melodies, for which the playwright would supply fresh lyrics; and during his decade as a dramatist, Fielding wrote eleven of them.

That he was attracted to ballad opera is understandable. If his first novel Joseph Andrews (1742) parodied Richardson's Pamela (1740) and his most enduring play Tom Thumb (1730) parodied heroic tragedy, this new musical form was itself satirical in nature. The Beggar's Opera offered a lively burlesque of contemporary fashions, and unlike many of Gay's successors, Fielding embraced its comically subversive ways. In fact, both dramatists suffered the wrath of the Walpole administration for their use of political satire. If Polly (1729), the sequel to The Beggar's Opera, was banned by the authorities, Fielding's Deborab ${ }^{2}$ (1733) and The Grub-Street Opera (1731) were similarly suppressed, with Walpole ultimately using the Licensing Act to cut Fielding's theatrical career short.

The government, however, was not the only satirical target that the playwrights shared. As its oxymoronic name suggests, ballad opera was in part a comic reaction to opera seria, similar in its way to such other nationalistic responses as Italian opera buffa and German Singspiel. Indeed, there was considerable cross-pollination between the various native forms. For example, Singspiel arose out of translations of ballad operas while Gay and Fielding themselves were likely influenced by Paris's comedies en vaudevilles, a genre that "later transformed - with the introduction of Italianate airs in the style of the intermezzi- into opera comique" (Rogers 2007: 115).

If Gay in 1728 chose to satirize Italian opera, it was in fact ripe for such a treatment. The import had recently taken London by storm and had so enthralled

\footnotetext{
1. See, for example, Winn (1981: 247-248) on Addison's "complacent amateurism" and Rumbold (2000: 65) on Pope.

2. For the argument that the play was suppressed for political reasons, see Battestin (1989: 164-165).
} 
the public that rival companies, Handel's and the Opera of the Nobility, were soon locked in a bidding war for talent from Italy. Fielding (2004: 299) summed up the situation in the epilogue to The Author's Farce:

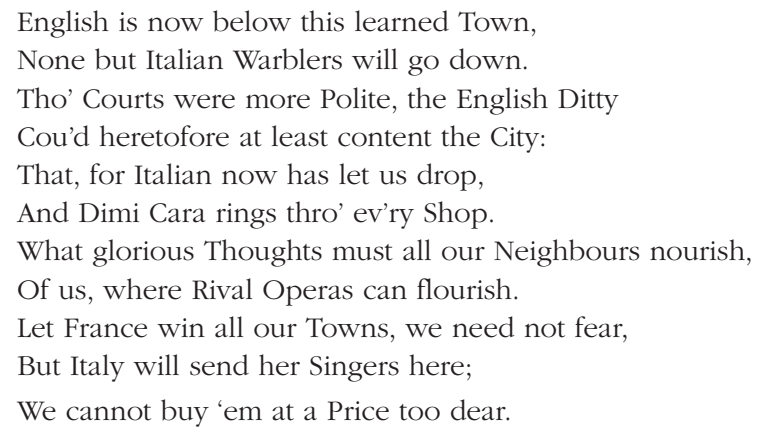

As these lines suggest, while the public relished the import, Fielding did not, and initially self-interest may have played a part. As a practicing dramatist, his works were vying for audiences with the expensive Italian operas as the oftenimpoverished Fielding was keenly aware. In fact, while recent scholarship (Joncus 2006: 201) has raised doubts about the legitimacy of his claim, he repeatedly alleged that Italian opera was siphoning off spectators and money from English entertainments like his own. For example, in Tumble-Down Dick (1736), he has an on-stage dramatist complain that he "can't see why a player of our own country, and in our own language, should not deserve five hundred [pounds], sooner than a saucy Italian singer twelve" (Fielding 1903b: 29).

Fielding's criticism of the genre, though, did not lessen after the Licensing Act of 1737 halted his own dramatic career, by which point opera's initial London heyday was ending as well. Indeed, by the year of the Act, the great castrati Senesino and Farinelli had left the country while the warring of the rival companies was effectively bankrupting both. Handel gradually abandoned the form in favor of oratorios, and the Opera of the Nobility found itself on such shaky financial footing that the directors sued their subscribers for funds.

Far from stopping, however, Fielding's attacks continued with such force that we find him accusing the genre's aficionados of "the most depraved Levity of Mind, an utter Insensibility of Public Good or Evil" (Fielding 1987b: 170). In point of fact, the "Public Good" was at the heart of his persistent antagonism to opera, for the danger he perceived from it was ultimately less to himself than to the nation.

Fielding was English to the core. When he formed his own dramatic troupe, he named it the Great Mogul's Company of English Comedians, and the lyrics to his most popular song stand in themselves as testament to his outspokenly patriotic stance: 


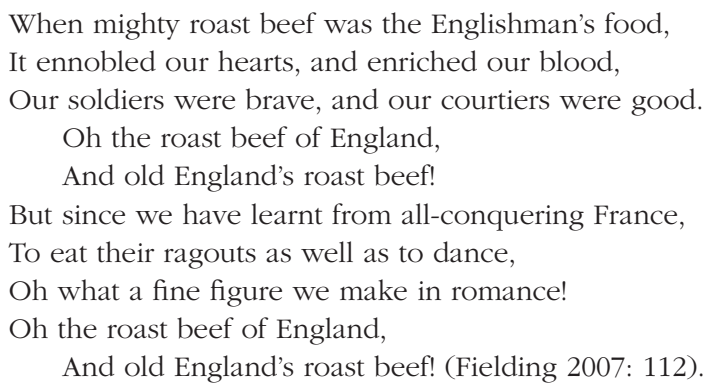

If Fielding favored the traditionally English in matters culinary, the same was true in matters musical. Suzanne Aspden (1997: 49) has shown that the early eighteenth century's growing interest in ballads sprang in part from a desire "to enforce British nationalism through identifiably British art forms", and Fielding's works clearly reflect this fact. Indeed, in one play he stages an actual singing competition between the Italian Signior Cantileno and the native Mr. Ballad, who predictably triumphs and wins the fair maiden as well (Fielding 1903c: 464-465).

Fielding's jingoistic hostility to opera was raised to a fever pitch during the Jacobite uprising of 1745 . In his aptly named journal The True Patriot, he even resurrected one of his most famous characters to define the Italian import. As Abraham Adams describes it, opera "is a Diversion in which a prodigious Sum of Money, more than is to be collected out of twenty Parishes, is lavish'd away on [...] Papists, very scandalous to be suffered at any Time, especially at a Season when both War and Famine hang over our Heads" (Fielding 1987b: 202).

The reference to papists is a telling one since it suggests a religious component to Fielding's antipathy. As William Weber (1997: 50-52) has noted, this was not uncommon among writers of the day. In Steele's play The Tender Husband (1705), for example, the epilogue damns the castrati by terming their performances "Popery in Wit./The Songs [...] from Rome they bring; /And 'tis High-Mass, for ought you know, they Sing" (Steele 1971: 273). In fact, one particularly rabid writer went so far as to issue a dire warning about a leading castrato in a tract entitled "A Protestant Alarm to Great Britain: Proving [...] Senesino [...] is no Eunuch, but a Jesuit in Disguise" (quoted in Cervantes 1998: 19).

The general sense of religious concern underlying such a charge would have resonated with Fielding. As children, he and his siblings were raised to be staunchly anti-Catholic and were the subject of a custody battle involving that very issue. When his mother died, his father married a member of the Church of Rome, much to the displeasure of Fielding's maternal grandmother, who feared the woman would convert the children to the anti-Christ. It was even alleged that the new wife locked up the King James Bible to prevent the children from reading it 
and then deliberately left "her own Romish Prayer Books in the Windows of the Roomes where the said Children used to go" (quoted in Thomas 1990: 28). The grandmother sued for custody and won.

Consequently, it is not surprising that Fielding regarded Italian music and musicians as suspect on religious grounds. Indeed, with Bonnie Prince Charlie advancing toward London, he wrote an essay linking the importation of opera singers with an attempt by the Pope to impose Catholicism on England. As Fielding (1987a: 97-98) has the Pontiff declare, "At a Time when their Country is engag'd in a War abroad, and invaded at home, they [...] import Italian Singers [...]. If this be the Case, what think you of my Hopes, Brother?" In the essay, the Pope's brother is the devil.

Moreover, it was not merely that Fielding saw the popularity of opera as betraying the nation; he saw it as potentially corrupting the nation and in more than a strictly religious sense. Fielding was a firm believer in music's ability to affect an audience, for good or ill. Relevant in this connection is the fact that time and again, his writings cite the story of Orpheus, the man whose music could enchant wild beasts. According to the myth, so beautiful were his tunes that they caused the very rocks and trees to move as they followed his sound; and when Orpheus then descended to the underworld to plead for the restoration of his dead wife, his music so captivated the King of Hades that he granted his request.

Given the frequency with which he refers to it (e.g., 1972a: 77; 1988: 98; 1993b: 37, 109; 2004: 259, 281, 300; Grundy 1972: 230), it is clear that Fielding viewed this myth as the defining metaphor for the power of music. In fact, he went on to write an entire play about Orpheus's journey to the underworld, in which his singing causes Pluto to melt into "Raptures", cry out "O caro, caro", and surrender with the words, "I am conquered; by Styx, you shall have her back. Take my Wife too, take every thing" (Fielding 1993a: 137, 139). Interestingly, in his version of the myth, Fielding depicts Orpheus, the consummate musician, as an Italian opera singer.

This may at first seem contradictory given his hostility to the genre. However, Fielding's antagonism toward opera was never rooted in a failure to appreciate its beauty. Paradoxically, it was rooted in the reverse -in his full recognition of the power of its "soft alluring Strain" (Fielding 2004: 352). Indeed, Orpheus is not the only mythical figure to whom he compares the Italians. He links them with the sirens as well (Fielding 2004: 350); and if the irresistible singing of those creatures lured sailors to destruction, he feared that opera's strong appeal might similarly overwhelm his fellow citizens to their and the nation's detriment.

As Thomas McGeary (1994: 20-21) has noted, Fielding was not alone in this. For example, his fellow dramatist John Dennis (quoted in Fiske 1973: 49) spoke with alarm of the "influence the soft and effeminate Measures of the Italian Opera have upon the Minds and Manners of Men. The modern Italian men [...] 
are neither Vertuous, nor Wise, nor Valiant; and they who have reason to know their Women, never trust them out of their sight". Fielding (1987b: 167) shared Dennis's view and flatly declared "that the Softness of Italian Music is calculated to enervate the Mind".

"Soft" is Fielding's regular adjective for opera (e.g., 1903b: 465; 1973: 52; 1993a: 137; 2004: 300, 352; Grundy 1972: 239), and for him its potential to emasculate was symbolized by the type of male singer it featured. Castrati achieved a remarkable success on the early eighteenth-century English stage. Most notably, Carlo Broschi, better known as Farinelli, sang in London to great acclaim from 1734 to 1737, a fact that Fielding (1967b: 25) labels "ominous, for if we go on to improve in luxury, effeminacy, and debauchery, as we have done lately, the next age [...] may be more like the children of squeaking Italians than hardy Britons".

His most graphic depiction of this feared emasculation comes in one of his livelier exercises in Swiftian satire. In this essay Fielding advocates putting the opera house to new use after the season ends. For the benefit of the nation, he argues, the army should be assembled there along with a staff of doctors, who by performing the necessary surgery could turn the soldiers themselves into singers. As Fielding (1989: 342) explains,

For some Time after the Abscission, They must be kept without Light, to prevent Fevers; but as no Endeavours should be omitted to prevent any Loss of Time [...], I would have Them, like Linnets, taught Tunes in the dark. In three Years, at farthest, the whole Operation might be compleated, and our Army made to out-sing any Army in Europe, which would render Them of still greater Advantage to their Country.

He concludes by suggesting the procedure be repeated with a squadron of sailors, after which the cannons at the portholes could be replaced with bassoons.

Fielding's fear that Italian opera might melt the mettle of the English male was matched by his concern that it might also melt the English female though in a rather different way. In The Author's Farce (1730), he has Mrs. Novel, a parody of Eliza Haywood, sing to Signior Opera, "Beauties who subdue Mankind,/Thy soft Chains alone can bind;/See within their lovely Eyes/The melting Wish arise" (Fielding 2004: 352).

Contemporary accounts suggest that there was some truth to Mrs. Novel's words. In Joseph Andrews, the sexually predatory Mrs. Slipslop may declare that she hates "the Sight of [Mophrodites] even singing in an Opera" (Fielding 1967a: 43), but many London females would have disagreed. In fact, when Farinelli sang there, a woman in the audience was so overcome that she famously cried out in semi-blasphemous ecstasy, "One God, one Farinelli" (Barbier 1996: 183). Indeed, in The Historical Register for the Year 1736, Fielding (1967b: 24) has an entire circle of women give voice to a similar passion: 


\begin{abstract}
All ladies: "Was you at the Opera, madam, last night?" Second lady: "Who can miss an opera while Farinello [sic] stays?" Third lady: "Sure he is the charmingest creature!" Fourth lady: "He's everything in the world one could wish!" First lady: "Almost everything one could wish!"
\end{abstract}

The apparent irrationality of this romantic infatuation with castrati served to reinforce a belief held by many critics of the form. With respect to Alexander Pope, Robert Ness (1986-1987: 178) has written that the triumph of the genre suggested "sound without sense had arrived, a musical performance of an alien art in a language as meaningless to most Englishmen as the [...] cultural values which had produced [...] the castrati".

Fielding too saw opera as senseless, as is evident in his works from the company it routinely keeps. For example, in The Champion (1739-1740) he proposes the establishment of a "Hospital for Fools", declaring that "we will allow them all the Amusements they have at present, and fling them, in a Heap, all their [...] Operas, Puppet-shews, Raree-shews, Pantomimes, Dexterity of Hand" (Fielding 2003: 197). Fielding may himself have been a master of comedy, but as this suggests, his objection to opera seria was certainly not its seriousness. Indeed, in later years he actually implied his preference within the genre for Handel's "solemn, sublime" efforts over the lighter ones that followed (Fielding 1993c: 191). ${ }^{3}$

Rather, Fielding opposed Italian opera on the same grounds that he did rareeshows: sung in a language unintelligible to the audience, it might appeal to the ear, it might appeal to the eye, but it did not appeal to the mind. So firmly did he believe this that he concluded his first great theatrical success with an allegorical union in which Signior Opera makes a divine conquest by serenading the Goddess of Nonsense, who cries out "in an Ecstasy", "Bravissimo! I long to be your Wife" (Fielding 2004: 343).

Opera's failure to inform the mind violated Fielding's neoclassical belief that art must be instructive. In fact, citing the Greeks, he acknowledged the "great Power over the Passions, which the ancient Philosophers assigned to Music". However, he also noted that Plato "considered the Application of it to Amusement only, as a high Perversion [...] for he imagin'd it given by the Gods to Men for much more divine and noble Purposes" (Fielding 1987b: 166). Those purposes were to educate and improve, and from Fielding's perspective Italian opera failed to do this in a uniquely extravagant way.

Moreover, if opera challenged his aesthetic in that regard, it did so in another. As Dean Mace (1970: 2-3) has pointed out, "since the Italians had flooded Europe with

3. See Cervantes (1996: 166-167) on this passage. Also, see Fielding (1903a: 29; 1975a: 463; 1987b: 425) and his ironic treatment of Squire Western's preference for "light and airy" music over Handel's in Tom Jones (1975b: 169). 
commentaries on Aristotle's Poetics, [...] poetry reigned supreme in the hierarchy of the arts, because the word was assumed to be synonymous with reason, and the most significant human experience was thought to be in some sense rational". By the eighteenth century, that view was weakening on the Continent as the forces that would lead to Romanticism gained strength, but it remained entrenched among many in England.

For example, Fielding's closest friend James Harris (1970: 102) wrote a treatise contending that "Music, when alone, can only raise Affections, which soon languish and decay, if not maintained and fed by the nutritive Images of Poetry. Yet must it be remembered, in this Union, that Poetry ever have the Precedence; its Utility, as well as Dignity, being by far the more considerable". Fielding agreed and accepted the supremacy of the word over "Musick for soft Brains" (1960: 20). Italian opera, on the other hand, in reducing words to inconsequence and transporting through sheer sound, completely overturned this hierarchy, as the handmaid music became the mistress.

That this played a role in Fielding's rejection of the genre is reflected in his shifting attitude toward Handel over the years. While the composer was writing operas, Fielding attacked him, linking him with "Scriblers" in one work (Fielding 1972b: 27) and with his perennial target Colley Cibber in another (Fielding 1989: 343). However, his opinion underwent a sea change once Handel moved from Italian opera to English oratorio, a musical genre "more essentially verbal than any other form of English-language theatre (at no other did the patrons actually have the words in front of them during the performance)" (Smith 1995: 76).

Once the composer had made this transition, Fielding waxed lavish in his praise. Where earlier he had associated him with Cibber, he now associated him with Shakespeare (Fielding 1987b: 104) and christened him "the greatest Master in Europe" (Fielding 2003: 237). In his final and most sentimental novel, Fielding (1983: 188-189) even has his moral exemplar, his idealized heroine Amelia, attend one of the oratorios since she is "a great Lover [...] of Mr. Handel's Compositions". She reads the libretto as the music plays, the primacy of the word restored.

By the time Fielding wrote Amelia in 1751, the musical scene in England was changing. Italian opera had ceased to be all the rage, and ballad opera itself had faded. In its place arose another indigenous form, comic opera, a hybrid that was substantially influenced by Continental models. Significantly, though, some who wrote it affirmed their debt to the precedent set by authors like Fielding. In 1780, for example, in the preface to The Lord of the Manor, John Burgoyne (1808: 136) asserted:

I cannot easily bring myself to allow the higher branch of our Comic Opera to be of foreign extraction. From the time the Beggar's Opera appeared, we find pieces in 
prose, with songs interspersed, so approaching to regular Comedy in plot, incident, and preservation of character, as to make them a distinct species from any thing we find abroad -and is it too much to add that the sense, wit, and humour to be found in some of them are sterling English marks by which we may claim the species as our own?

It is certainly true that, despite Fielding's attacks, Italian opera continued to hold the stage and attract a cultured if limited audience. However, as his era's most prolific writer of ballad operas, Fielding played his part in establishing the viability of a homegrown comic alternative in which song served story. In achieving this, he may not have driven the foreign import from the land, but he did help institute a native tradition that became an enduring part of the English musical world.

\section{REFERENCES}

Aspden, S. 1997. "Ballads and Britons: Imagined Community and the Continuity of 'English' Opera”. Journal of the Royal Musical Association 122 (1): 24-51.

Barbier, P. 1996. The World of the Castrati. London: Souvenir Press.

Battestin, M. 1989. Henry Fielding: A Life. New York: Routledge.

Burgoyne, J. 1808 (1780). The Lord of the Manor. The Dramatic and Poetical Works of the Late Lieut. Gen. J. Burgoyne. London: C. Whittingham.

Cervantes, X. 1996. "Playwright Henry Fielding: Enemy or Connoisseur of Italian Opera?” Theatre History Studies 16: 157-172.

Cervantes, X. 1998. "Tuneful Monsters': the Castrati and the London Operatic Public, 1667-1737". Restoration and Eighteenth-Century Theatre Research 13 (1): $1-24$.

Fielding, H. 1903a (1747). Familiar Letters. The Complete Works of Henry Fielding, Esq. Vol. 3. Ed. W. E. Henley. London: William Heinemann.

Fielding, H. 1903b (1736). Tumble-Down Dick. The Complete Works of Henry Fielding, Esq. Vol. 5. Ed. W. E. Henley. London: William Heinemann.

Fielding, H. 1903c (1742). Miss Lucy in Town. The Works of Henry Fielding, Esq. Vol. 3. Ed. J. Browne. London: Bickers and Son.

Fielding, H. 1960 (1731). Epilogue to Theobald, L. Orestes. The Female Husband and Other Writings. Ed. C. E. Jones. Liverpool: Liverpool University Press.

Fielding, H. 1967a (1742). Joseph Andrews. Ed. M. C. Battestin. Middletown, CT: Wesleyan University Press.

Fielding, H. 1967b (1737). The Historical Register for the Year 1736. The Historical Register for the Year 1736 and Eurydice Hissed. Ed. W. W. Appleton. Lincoln, NE: University of Nebraska Press. 
Fielding, H. 1972a (1743). "The Cat and the Fiddle". Miscellanies by Henry Fielding, Esq. Vol. 1. Ed. H. K. Miller. Middletown, CT: Wesleyan University Press.

Fielding, H. 1972b (1741). "Of True Greatness". Miscellanies by Henry Fielding, Esq. Vol. 1. Ed. H. K. Miller. Middletown, CT: Wesleyan University Press.

Fielding, H. 1973 (1736). Pasquin. Eds. O. M. Brack, Jr., W. Kupersmith, and C. Zimansky. Iowa City, IA: University of Iowa Press.

Fielding, H. 1975a (1747-1748). The Jacobite's Journal. The Jacobite's Journal and Related Writings. Ed. W. B. Coley. Middletown, CT: Wesleyan University Press.

Fielding, H. 1975b (1749). The History of Tom Jones, a Foundling. Ed. F. Bowers. Middletown, CT: Wesleyan University Press.

Fielding, H. 1983 (1751). Amelia. Ed. M. C. Battestin. Middletown, CT: Wesleyan University Press.

Fielding, H. 1987a (1745). "A Dialogue Between the Devil, the Pope, and the Pretender". The True Patriot and Related Writings. Ed W. B. Coley. Middletown, CT: Wesleyan University Press.

Fielding, H. 1987b (1745-1746). The True Patriot. The True Patriot and Related Writings. Ed. W. B. Coley. Middletown, CT: Wesleyan University Press.

Fielding, H. 1988 (1752). The Covent-Garden Journal. The Covent-Garden Journal and a Plan of the Universal Register Office. Ed. B. A. Goldgar. Middletown, CT: Wesleyan University Press.

Fielding, H. 1989 (1734-1739). The Craftsman. New Essays by Henry Fielding: His Contributions to the Craftsman (1734-1739) and Other Early Journalism. Ed. M. C. Battestin. Charlottesville, VA: University Press of Virginia.

Fielding, H. 1993a (1737). Eurydice. Miscellanies by Henry Fielding, Esq. Vol. 2. Ed. H. Amory. Middletown, CT: Wesleyan University Press.

Fielding, H. 1993b (1743). A Journey from This World to the Next. Miscellanies by Henry Fielding, Esq. Vol. 2. Ed. H. Amory. Middletown, CT: Wesleyan University Press.

Fielding, H. 1993c (1743). The Wedding Day. Miscellanies by Henry Fielding, Esq. Vol. 2. Ed. H. Amory. Middletown, CT: Wesleyan University Press.

Fielding, H. 2003 (1739-1740). The Champion. Contributions to The Champion and Related Writings. Ed. W. B. Coley. Oxford: Clarendon Press.

Fielding, H. 2004 (1730). The Author's Farce. Plays, Volume One, 1728-1731. Ed. T. Lockwood. Oxford: Clarendon Press.

Fielding, H. 2007 (1731). The Grub-Street Opera. Plays, Volume Two, 1731-1734. Ed. T. Lockwood. Oxford: Clarendon Press. 
Fiske, R. 1973. English Theatre Music in the Eighteenth Century. London: Oxford University Press.

Grundy, I. M. 1972. "New Verse by Henry Fielding". Publications of the Modern Language Association of America 87 (2): 213-245.

Harris, J. 1970 (1744). Three Treatises. New York: Garland.

Joncus, B. 2006. "Handel at Drury Lane: Ballad Opera and the Production of Kitty Clive". Journal of the Royal Musical Association 131 (2): 179-226.

Mace, D. 1970. "Marin Mersenne on Language and Music". Journal of Music Theory 14 (1): 2-34.

McGeary, T. 1994. "Gendering Opera: Italian Opera as the Feminine Other in Britain, 1700-1742”. Journal of Musicological Research 14: 17-34.

Ness, R. 1986-1987. "The Dunciad and Italian Opera in England". EighteenthCentury Studies 20 (2): 173-194.

Rogers, V. 2007. Writing Plays "in the Sing-Song Way": Henry Fielding's Ballad Operas and Early Musical Theater in Eighteenth-Century London. Dissertation. (Ph.D.). University of Southern California.

Rumbold, V. 2000. "Ideology and Opportunism: the Role of Handel in Pope's The Dunciad in Four Books". "More Solid Learning": New Perspectives on Alexander Pope's 'Dunciad'. Eds. C. Ingrassia and C. N. Thomas. Lewisburg, PA: Bucknell University Press. 62-80.

Smith, R. 1995. Handel's Oratorios and Eighteenth-Century Thought. New York: Cambridge University Press.

Steele, R. 1971 (1705). The Tender Husband. The Plays of Richard Steele. Ed. S. S. Kenny. Oxford: Clarendon Press.

Thomas, D. 1990. Henry Fielding. New York: St. Martin's Press.

Weber, W. 1997. "Handel's London - Social, Political and Intellectual Contexts". The Cambridge Companion to Handel. Ed. D. Burrows. Cambridge, UK: Cambridge University Press. 45-54.

Winn, J. A. 1981. Unsuspected Eloquence: a History of the Relations Between Poetry and Music. New Haven, CT: Yale University Press. 